\title{
Ergonomie : une approche anthropotechnologique dans la conception des systèmes de travail. Semaine d'Anthropologie de Paris I
}

Philippe Geslin

\author{
(2) OpenEdition \\ Journals \\ Édition électronique \\ URL : https://journals.openedition.org/tc/635 \\ DOI : $10.4000 /$ tc. 635 \\ ISSN : 1952-420X \\ Éditeur \\ Éditions de l'EHESS
}

Édition imprimée

Date de publication : 1 mars 1995

ISSN : 0248-6016

Référence électronique

Philippe Geslin, «Ergonomie : une approche anthropotechnologique dans la conception des systèmes de travail. Semaine d'Anthropologie de Paris I », Techniques \& Culture [En ligne], 22 | 1995, mis en ligne le 05 janvier 2006, consulté le 29 septembre 2022. URL : http://journals.openedition.org/tc/635 ; DOI : https://doi.org/10.4000/tc.635

Ce document a été généré automatiquement le 29 septembre 2022

Tous droits réservés 
Ergonomie : une approche anthropotechnologique dans la conception des systèmes de travail. Semaine d'Anthropologie de Paris I

Philippe Geslin 